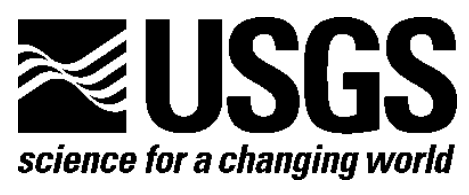

Prepared in cooperation with the Great Lakes Restoration Initiative

\title{
Determination of the Acute Toxicity of Isoniazid to Three Invasive Carp Species and Rainbow Trout in Static Exposures
}

By Theresa M. Schreier and Terrance D. Hubert

Open-File Report 2015-1101

U.S. Department of the Interior

U.S. Geological Survey 


\title{
U.S. Department of the Interior SALLY JEWELL, Secretary
}

\section{U.S. Geological Survey Suzette M. Kimball, Acting Director}

\author{
U.S. Geological Survey, Reston, Virginia: 2015
}

For more information on the USGS-the Federal source for science about the Earth, its natural and living resources, natural hazards, and the environment-visit http://www.usgs.gov or call 1-888-ASKUSGS (1-888-275-8747)

For an overview of USGS information products, including maps, imagery, and publications, visit http://www.usgs.gov/pubprod

Any use of trade, firm, or product names is for descriptive purposes only and does not imply endorsement by the U.S. Government.

Although this information product, for the most part, is in the public domain, it also may contain copyrighted materials as noted in the text. Permission to reproduce copyrighted items must be secured from the copyright owner.

Suggested citation:

Schreier, T.M., and Hubert, T.D., 2015, Determination of the acute toxicity of Isoniazid to three invasive carp species and rainbow trout in static exposures: U.S. Geological Survey Open-File Report 2015-1101, 9 p., http:/dx.doi.org/10.3133/ofr20151101.

ISSN 2331-1258 (online) 


\section{Acknowledgments}

The authors thank personnel from the Upper Midwest Environmental Sciences Center, including Scott Porcher for assisting with data collection and Steve Redman and Matt Paulson for care and maintenance of the test organisms. 



\section{Contents}

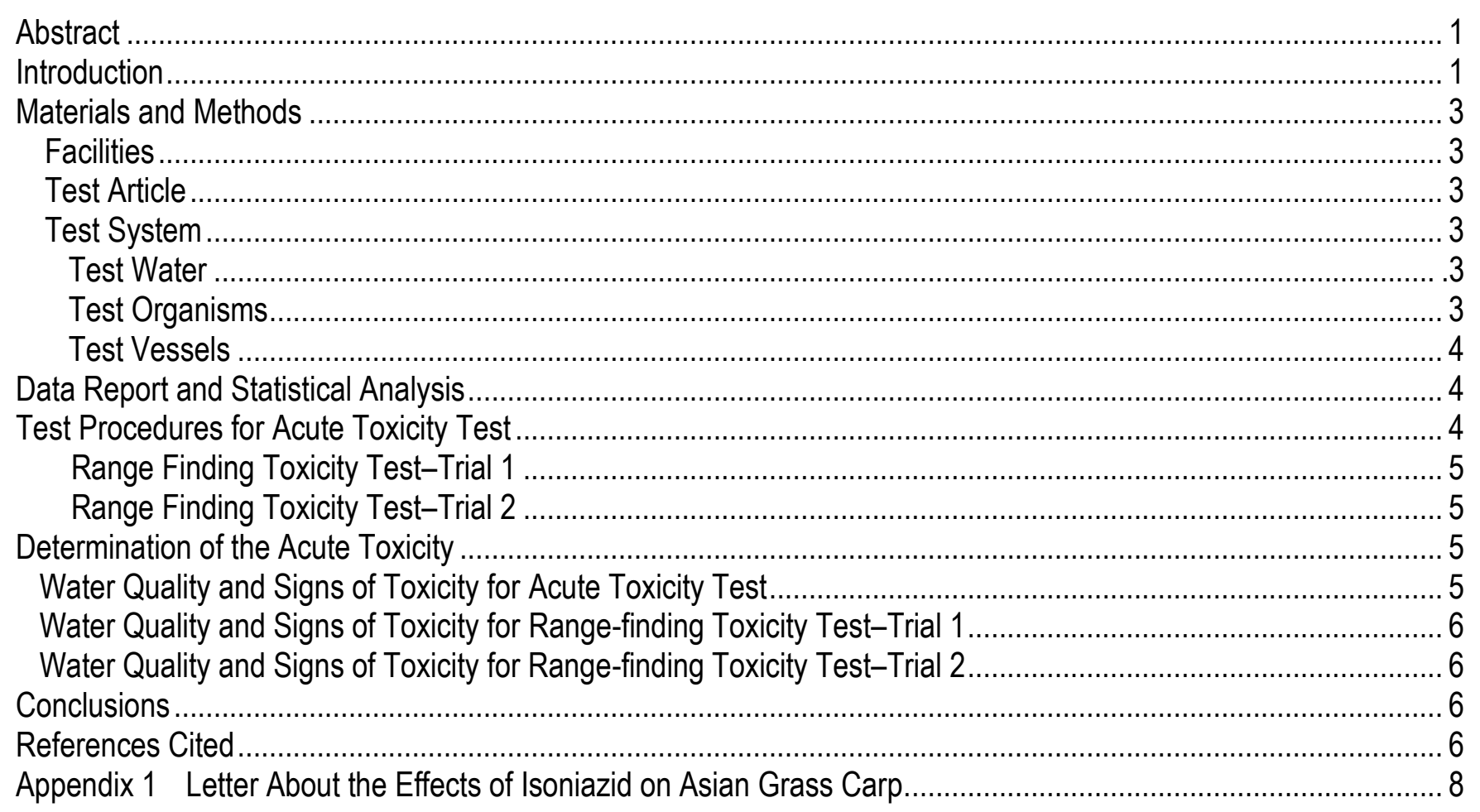

\section{Figure}

1. Diagram showing chemical structure of Isoniazid ............................................................................ 3 


\section{Conversion Factors}

International System of Units to Inch/Pound

\begin{tabular}{llll}
\hline & Multiply & By obtain \\
\hline & Length & \\
\hline centimeter (cm) & 0.3937 & inch (in.) \\
millimeter (mm) & 0.03937 & inch (in.) & \\
\hline \multicolumn{4}{c}{ Volume } \\
\hline liter (L) & 0.264172 & gallon (gal) \\
liter (L) & 1.057 & quart (qt) \\
milliliter (mL) & 0.03382 & ounce, fluid (fl. oz) \\
& & \\
\hline & \multicolumn{2}{c}{ Mass } & \\
\hline gram (g) & 0.03527 & ounce, avoirdupois (oz) \\
milligram (mg) & $3.527 \times 10^{-5}$ & ounce, avoirdupois (oz) \\
\hline
\end{tabular}

Temperature in degrees Celsius $\left({ }^{\circ} \mathrm{C}\right)$ may be converted to degrees Fahrenheit $\left({ }^{\circ} \mathrm{F}\right)$ as ${ }^{\circ} \mathrm{F}=\left(1.8 \times{ }^{\circ} \mathrm{C}\right)+32$.

\section{Abbreviations}

DO dissolved oxygen

LC lethal concentration, LC50 and LC 99.9 in milligrams per liter

SOP standard operating procedures

UMESC Upper Midwest Environmental Sciences Center of the U.S. Geological Survey

USGS U.S. Geological Survey 


\title{
Determination of the Acute Toxicity of Isoniazid to Three Invasive Carp Species and Rainbow Trout in Static Exposures
}

\author{
By Theresa M. Schreier and Terrance D. Hubert
}

\begin{abstract}
Three invasive fishes of considerable concern to aquatic resource managers are the Hypophthalmichthys nobilis (bighead carp), Hypophthalmichthys molitrix (silver carp), and Ctenopharyngodon idella (grass carp), collectively known as Asian carps. There is a need for an effective chemical control agent for Asian carps. Isoniazid was identified as a potential toxicant for grass carp. The selective toxicity of isoniazid to grass carp was verified as a response to an anecdotal report received in 2013. In addition, the toxicity of isoniazid to bighead carp, silver carp, and Oncorhynchus mykiss (rainbow trout) was evaluated. Isoniazid was not toxic to grass carp at the reported anecdotal concentration, which was 13 milligrams per liter. Isoniazid (130 milligrams per liter) was not selectively toxic to bighead carp, silver carp, or grass carp when compared to rainbow trout.

\section{Introduction}

Three invasive fishes of considerable concern to aquatic resource managers are the Hypophthalmichthys nobilis (bighead carp), Hypophthalmichthys molitrix (silver carp), and Ctenopharyngodon idella (grass carp), collectively known as Asian carps. Bighead and silver carp were introduced into the United States waters in the 1970s and have now become established in the central and east central United States. Grass carp were introduced into the United States in 1963 for aquatic-weed control (Guillory and Gasaway, 1978).

Originally from eastern Asia, bighead and silver carp were imported to the United States to improve water clarity in aquaculture ponds and sewage treatment facilities (Kolar and others, 2005). Flooding events in the early 1970s allowed access to natural waterways such as the Mississippi River, where the fishes were able to thrive and spread farther within the Mississippi River drainage basin (Kolar and others, 2007). Because of their large size (average weight 30-40 pounds), high reproductive rate, and rapid growth, they threaten to out-compete native fish species for plant and animal plankton by eating up to 20 percent of their body weight each day and compose a substantial fraction of the biomass in parts of the Illinois and Mississippi Rivers (Kolar and others, 2007; Johnson and Hagerty, 2008). Silver carp cause harm when they become agitated by sound and vibration and leap out of the water hitting boats and passengers (Kolar and others, 2007). In addition, Asian carps could pose a substantial economic threat to the Great
\end{abstract}


Lakes commercial and sport fishing industry if these fish were to become established in the basin (American Sportfishing Association [ASA], 2008).

Grass carp were introduced by both authorized and unauthorized stockings for biological control of vegetation. This species was first imported to the United States in 1963 to aquaculture facilities in Auburn, Alabama, and Stuttgart, Arkansas. The first report of an unintentional release of this species into open water occurred at Stuttgart, Ark., when fish escaped the Fish Farming Experimental Station (Courtenay and others, 1984). However, many of the earlier releases in Arkansas included intentional stockings in lakes or reservoirs open to other stream systems allowing them to expand their range. By the early 1970s, reports of grass carp captured in the Missouri River and Mississippi River were more common (Pflieger, 1997). During the past few decades, the species has spread rapidly as a result of intentional stockings by Federal, State, and local government agencies, legal and illegal interstate transport and release of diploid fish by individuals and private groups, escapes from farm ponds and aquaculture facilities, and natural dispersal from introduction sites (for example, Pflieger, 1997; Lee and others, 1980; Dill and Cordone, 1997). Stocking of grass carp as a biological control against nuisance aquatic plants in ponds and lakes continues. Though most states require intentionally stocked grass carp to be triploid, diploid fish are still reared and sold by fish farmers in the United States.

Because of the negative impact of grass, bighead, and silver carp in aquatic ecosystems, an eradication or control method would be highly valued by aquatic resource managers.

Chemical control is one option routinely used to control invasive species. Currently (2015), there are only four registered fish toxicants approved for use to control aquatic invasive fish: the larval lampricides 3-trifluoromethyl-4-nitrophenol (TFM) and niclosamide, and the general fish toxicants rotenone and antimycin A. The lampricides are restricted use pesticides used almost exclusively for control of Petromyzon marinus (sea lamprey) in the Great Lakes Basin but in rare cases have been used to control aquatic invertebrates. Because rotenone and antimycin A are nonselective toxicants, they can be used only in circumstances where a complete eradication of all fishes can be tolerated (for example, as part of a reclamation/restoration project). The latter two chemicals have been used extensively by fisheries managers in North America for more than 60 years for the management and assessment of fish populations in lakes, ponds, and streams (Ling, 2002).

An anecdotal report received by the Council of Environmental Quality in 2013 (appendix 1) suggested that the compound isoniazid may be selectively toxic toward grass carp. An aquarist who had been employed by the former Cleveland Aquarium reported that the chemical appeared to selectively kill grass carp during a treatment to control mycobacteriosis on other fishes in the aquarium community (appendix 1). All grass carp were found dead on the day following the isoniazid treatment. Isoniazid is an antibiotic that has been used as a treatment for human tuberculosis and has been effective in treating valuable ornamental fish for mycobacteriosis (Munn, 2011).

The purpose of this report is to document the methods and results of experimental treatment of grass carp with isoniazid. The objectives of this experiment were to 1) verify the results of reported selective toxicity findings of isoniazid to grass carp and 2) determine if the selectivity extends to other invasive carp species. 


\section{Materials and Methods}

\section{Facilities}

All work was conducted at the Upper Midwest Environmental Sciences Center of the U.S. Geological (USGS-UMESC) according to applicable USGS-UMESC standard operating procedures (SOP). Research was conducted in a manner that minimized the spread of pathogens and invasive species.

\section{Test Article}

The test article was isoniazid, greater than 99 percent active ingredient, obtained from Sigma Aldrich Chemical Company, Milwaukee, Wisconsin. The test material structure is presented in figure 1 . For the static toxicity tests, nominal concentrations were used.<smiles>NNC(=O)c1ccncc1</smiles>

Figure 1. Diagram showing chemical structure of Isoniazid.

\section{Test System}

\section{Test water}

Toxicity was evaluated in USGS-UMESC well water maintained at three temperatures: 12 plus or minus $( \pm) 2$ degrees Celsius $\left({ }^{\circ} \mathrm{C}\right), 18 \pm 2{ }^{\circ} \mathrm{C}$ and $25 \pm 2{ }^{\circ} \mathrm{C}$, regulated in either a flowthrough holding tank or held at room temperature. Water-quality measurements including total hardness as calcium carbonate $\left(\mathrm{CaCO}_{3}\right)$ and total alkalinity as $\mathrm{CaCO}_{3}$ (American Public Health Association [APHA], 1985) were determined during the acute toxicity test and range-finding toxicity test-trial 2. Dissolved oxygen was monitored daily with an YSI 55 oxygen meter. Water temperature and $\mathrm{pH}$ were measured daily with a Beckman $\Phi 410 \mathrm{pH}$ meter.

\section{Test Organisms}

The bighead carp (mean-total length, $70 \pm 6$ millimeters [mm], mean weight, $3.0 \pm 1.0$ grams [g]) were obtained from the USGS Columbia Environmental Research Center (Columbia, Missouri). Silver carp (mean-total length, $71 \pm 5 \mathrm{~mm}$, mean weight, $2.7 \pm 0.5 \mathrm{~g}$ ) were collected by UMESC personnel by cast netting in water of high carp density in the Kansas River near Kansas City, Kansas. Diploid grass carp (mean-total length, $69 \pm 12 \mathrm{~mm}$, mean weight, $3.3 \pm$ $2.9 \mathrm{~g}$ were obtained from Osage Catfisheries (Osage, Mo.). Upon arrival at UMESC, all carp species were reared in the UMESC Invasive Species complex in recirculating culture tanks (60 inch diameter by 30 inch water depth, approximate volume 350 gallons) supplied with well water at approximately $20^{\circ} \mathrm{C}$. Prior to the acute toxicity test and the range-finding toxicity test-trial 2 , 
grass carp were acclimated to $12^{\circ}$ or $25^{\circ} \mathrm{C}$ at a rate of change of no more than $3{ }^{\circ} \mathrm{C}$ per day. Rainbow trout, Oncorhynchus mykiss, (mean-total length $60 \pm 5 \mathrm{~mm}$ and mean weight $1.9 \pm 0.4$ g) were obtained from Trout Lodge, Sumner, Washington, as eggs and reared in the UMESC aquaculture facility prior to use as a nontarget fish species in the toxicity trials. Test organisms were held according to UMESC SOPs for animal care and maintenance. Test animals were not fed (fasted) prior to testing.

All fishes were held a minimum of 14 days prior to testing to assess any delayed mortality due to transport and were admitted to the study only if the health and mortality history of the fishes conformed to UMESC SOPs. Fishes were used in all trials without regard to gender.

\section{Test Vessels}

Static toxicity tests were conducted in either 25 - or 50-liter (L) stainless-steel tanks. The size of the test vessels selected was determined by the size of the test fishes and the resulting biomass in the test tank. Fish biomass did not exceed 0.8 grams per liter, according to the established American Society for Testing and Materials (ASTM) guidelines (ASTM, 2007). Vessels were filled to appropriate volumes $(15,30$, or $45 \mathrm{~L})$ with well water. The size of fish used ranged from 1.5 to $12.6 \mathrm{~g}$. The experimental unit for this study was the test vessel.

\section{Data Reporting and Statistical Analysis}

Statistical analyses involved simple descriptive statistics for means and standard deviations of water characteristics. Lethal concentrations (LC50, LC99.9 milligram per liter $[\mathrm{mg} / \mathrm{L}])$ were not calculated because mortality was not observed.

\section{Test Procedures for Acute Toxicity Test}

The test was conducted with grass carp according to ASTM (2007). The grass carp were acclimated to $12{ }^{\circ} \mathrm{C}$ and feed was withheld for 72 hours before transfer to the test vessels. Ten fish were randomly assigned in the test vessels according to random numbers generated by Stat trek (www.stattrek.com/Tables/Random.aspx). The fish were exposed to six isoniazid concentrations spaced by a factor of $0.6(1.01,1.69,2.81,4.68,7.80$, and $13.0 \mathrm{mg} / \mathrm{L})$. The test concentrations were based on the reported anecdotal concentration reported from the Cleveland Aquarium (appendix 1), which was $13 \mathrm{mg} / \mathrm{L}$ isoniazid. Triplicate test vessels were prepared by addition of a specific volume of isoniazid spiking solution (concentration in deionized water). One well water control was included in the testing. Dissolved oxygen, $\mathrm{pH}$, and temperature were monitored daily in all test vessels. Mortalities were recorded at 1, 3, 6, 12, 24, 48, 72, and 96 hours of exposure. Length and weight measurements were recorded on the control group of fish at the end of the test. Any test fish alive at the end of the test were euthanized and disposed of according to UMESC SOPs. All exposure water containing isoniazid was passed through activated charcoal to trap remaining test chemical before being discharged from the facility. 


\section{Range-Finding Toxicity Test-Trial 1}

Because the toxicity reported in the anecdotal report was not observed in the grass carp acute toxicity test, a range-finding toxicity test was conducted simultaneously with grass, bighead, and silver carps and rainbow trout (nontarget species). The grass, bighead, and silver carp were tested at $18 \pm 2{ }^{\circ} \mathrm{C}$. Rainbow trout were tested at $12 \pm 2{ }^{\circ} \mathrm{C}$. Temperature acclimation was not required because the test was conducted at their respective rearing temperature. The fishes were fasted for 72 hours before transfer to the test vessels. Isoniazid concentrations of 26 $\mathrm{mg} / \mathrm{L}$ ( 2 times the reported toxic level) and $130 \mathrm{mg} / \mathrm{L}$ (10 times the reported toxic level) were evaluated. Each test concentration was tested as a single replicate per species (one test tank per concentration per species). A spiking standard of isoniazid for delivery to test vessels was prepared in deionized water. One well-water control was included for each fish species that was tested. Dissolved oxygen, $\mathrm{pH}$, and temperature in the test vessels were monitored daily. Mortalities were recorded at 1, 24, and 48 hours of exposure. Length and weight measurements were recorded for the control group of fishes at the end of the trial. Any test organisms alive at the end of the trial were euthanized and disposed of according to UMESC SOPs. All exposure water containing isoniazid was passed through activated charcoal to trap remaining test material before being discharged from the facility.

\section{Range-Finding Toxicity Test-Trial 2}

An additional range-finding trial was conducted on grass carp at $25^{\circ} \mathrm{C}$ to replicate the water temperature reported by the Cleveland Aquarium. The fish were acclimated for 3 weeks to the test temperature. The fish were fasted for 72 hours before transfer to the test vessels. Isoniazid concentrations of 13,26 , and $130 \mathrm{mg} / \mathrm{L}$ (equal to 1,2 , and 10 times the previously reported toxic level) were evaluated. Test procedures followed those of range-finding toxicity test-trial 1, except that test vessels were aerated with compressed air after low dissolved oxygen readings were observed after 24 hours of exposure.

\section{Determination of Acute Toxicity}

\section{Water Quality and Signs of Toxicity for Acute Toxicity Test}

The $\mathrm{pH}$ ranged from 7.68 to 7.95 , dissolved oxygen (DO) concentrations ranged from 5.90 to $8.81 \mathrm{mg} / \mathrm{L}$ and temperature ranged from 13.0 to $13.8^{\circ} \mathrm{C}$. There were only two DO readings throughout the trial that were below $6 \mathrm{mg} / \mathrm{L}$. Fish showed no clinical signs associated with oxygen stress. Alkalinity and water hardness were measured from the control and the highest isoniazid concentration at the beginning and end of the exposure. The mean alkalinity was $133 \mathrm{mg} / \mathrm{L}$ as $\mathrm{CaCO}_{3}$ and the mean water hardness was $172 \mathrm{mg} / \mathrm{L}$ as $\mathrm{CaCO}_{3}$. Neither sublethal signs of toxicity nor mortality were observed in any isoniazid test concentration. 


\section{Water Quality and Signs of Toxicity for Range-finding Toxicity Test-Trial 1}

The $\mathrm{pH}$ ranged from 7.58 to 7.87 , DO concentrations ranged from 3.30 to $8.39 \mathrm{mg} / \mathrm{L}$, and temperature ranged from 15.6 to $19.0{ }^{\circ} \mathrm{C}$ for the grass, silver and bighead carp tests and from 13.2 to $14.0{ }^{\circ} \mathrm{C}$ for the rainbow trout test. Dissolved oxygen concentrations were lowest in the test vessels with the highest isoniazid concentration $(130 \mathrm{mg} / \mathrm{L})$; clinical signs associated with oxygen stress were not observed. Neither sublethal signs of toxicity nor mortality were observed in either isoniazid concentration $(26$ or $130 \mathrm{mg} / \mathrm{L})$ tested.

\section{Water Quality and Signs of Toxicity for Range-finding Toxicity Test-Trial 2}

The $\mathrm{pH}$ ranged from 7.62 to 8.60 , DO concentrations ranged from 2.68 to $8.62 \mathrm{mg} / \mathrm{L}$ and temperature ranged from 23.8 to $24.4{ }^{\circ} \mathrm{C}$. After 24 hours, the dissolved oxygen in the highest isoniazid concentration $(130 \mathrm{mg} / \mathrm{L})$ test vessels was $2.69 \mathrm{mg} / \mathrm{L}$; clinical signs associated with oxygen stress were not observed. Aeration was added to all tanks and the DO concentrations increased and ranged from 7.29 to $8.62 \mathrm{mg} / \mathrm{L}$. The mean alkalinity was $130 \mathrm{mg} / \mathrm{L}$ as $\mathrm{CaCO}_{3}$ and the mean water hardness was $168 \mathrm{mg} / \mathrm{L}$ as $\mathrm{CaCO}_{3}$. Neither sublethal signs of toxicity nor mortality were observed in the isoniazid concentrations $(13,26$, or $130 \mathrm{mg} / \mathrm{L})$ tested.

\section{Conclusions}

The results indicate that isoniazid was not toxic to grass carp at the concentration suggested by the anecdotal report (13 milligrams per liter, appendix 1). In addition, isoniazid (130 milligrams per liter) was not selectively toxic to bighead carp, silver carp, or grass carp when compared to rainbow trout. Isoniazid tablet formulants were reviewed and the ingredients indicated no potential for toxic effects on grass carp. No additional research is planned using isoniazid or its tablet formulants for carp control.

\section{References Cited}

American Public Health Association (APHA), American Water Works Association, and Water Pollution Control Federation, 1985 (17th ed.): Standard methods for the examination of water and wastewater, Washington, D.C., 1586 p.

American Sportfishing Association, 2008, Today's angler-A statistical profile of anglers, their targeted species and expenditures: American Sportfishing Association, Alexandria, Va.

American Society for Testing and Materials (ASTM), 2007, Standard guide for conducting acute toxicity tests with fishes, macroinvertebrates and amphibians, (re-approved 2007): Annual Book of ASTM Standards, Standard E729-96, West Conshohocken, Pa.

Courtenay, W.R., Jr., Hensley D.A., Taylor J.N., and McCann J.A, 1984, Distribution of exotic fishes in the continental United States, in Courtenay, W. R, Jr., and Stauffer J.R., Jr., eds. Distribution, biology and management of exotic fishes: Baltimore, Md., Johns Hopkins University Press, p. 41-77.

Dill, W.A. and Cordone A.J., 1997, History and status of introduced fishes in California, 18711996: California Department of Fish and Game Fish Bulletin, v. 178, no. 1,413 p. 
Guillory, V. and Gasaway R.D., 1978, Zoogeography of the grass carp in the United States. Transactions of the American Fisheries Society, v. 107, p. 105-112.

Johnson, B.L. and Hagerty K.H., eds, 2008, Status and trends of selected resources of the Upper Mississippi River System -U.S. Geological Survey, Upper Midwest Environmental Sciences Center, Technical Report LTRMP 2008-T002 - 102 p., plus appendixes.

Kolar, C. S, Chapman, D.C, Courtenay, W.R., Housel, C.M., Williams, J.D, and Jennings, D.P., 2007, Bigheaded carps - A biological synopsis and environmental risk assessment: American Fisheries Society, Special Publication 33, 204 p.

Kolar, C.S., Chapman, D.C., Courtenay, W.R., Housel, C.M., Williams, J.D., and, Jennings, D.P., 2005, Asian carps of the genus Hypophthalmichthys (Pisces, Cyprinidae)-A biological synopsis and environmental risk assessment: Bethesda, Md., American Fisheries Society, 175 p.

Lee, D.S., Gilbert C.R., Hocutt C.H., Jenkins R.E., McAllister D.E., and Stauffer J.R., Jr., 1980, Atlas of North American freshwater fishes - Raleigh, N.C., North Carolina State Museum of Natural History, 854 p.

Ling, N., 2002, Rotenone-A review of its toxicity and use for fisheries management: New Zealand Department of Conservation, Science for Conservation, no. 211, 40 p.

Munn, C.B., 2011, Marine microbiology_Ecology and applications (2nd ed): in Almond, G. and Borrowdale, D. eds., Garland Science, Taylor and Francis Group, LLC., New York, N.Y., 320 p.

Pflieger, W.L., 1997, The fishes of Missouri (revised edition): Jefferson City, Mo., Missouri Department of Environmental Conservation, 372 p.

Stat Trek [2015], Random Number Generator Web page, accessed April 21, 2015, at www.stattrek.com/Tables/Random.aspx. 


\section{Appendix 1. Letter About the Effects of Isoniazid on Asian Grass Carp}

\section{Smithsonian}

National Zoological Park

John Goss, Asian Carp Director for the White House

EXECUTIVE OFFICE OF THE PRESIDENT

COUNCIL ON ENVIRONMENTAL QUALITY

WASHINGTON,D.C. 20503

Dear Mr. Goss,

It is my hope that your office can direct this letter to the appropriate staff on your team. Outlined below is the description of a set of circumstances where a small captive population of Asian grass carp Ctenopharyngodon idella were poisoned with medication that did not harm other species of fishes. Perhaps this information might be usefulin your efforts in controlling this invasive species.

\section{Background}

As an aquarist at the now-closed Cleveland Aquarium from $1970-1986$, I worked with a very diverse collection of marine and freshwater fishes and invertebrates. Unfortunately, specific records are not available so the following is from memory.

In one of our 12,000 gallon closed systems we maintained a diverse exhibit collection of temperate North American freshwater fishes. In the mid-70's that we obtained about eight fingerlings of the recently imported grass carp that were then considered a "wonder fish" for aquatic weed control. The grass carp were added to our North American fishes exhibit where they thrived growing to about five or six pounds fairly rapidly.

A virtually identical and separate 12,000 gallon system exhibited a diverse collection of Asian tropical fishes and included: tinfoil barbs Barbonymus schwanenfeldii; giant gourami Osphronemus goramy; kissing gourami Helostoma temminkii; snakehead Channa sp.; tricolor sharkminnow Balantiocheilos melanopterus; Datnnoides sp.; red scat Scatophagus argus; Monodacty/us sebae; walking catfish Clarias batrachus; Scleropages sp.; giant dania Devario aequipinnatus; black sharkminnow Labeo chrysophekadion; Pangas catfish Pangasius sp.; clown knifefish Chitala chitala; and others.

Within the Asian tropical fishes exhibit was a school of about ten tinfoil barbs that were very large (about $4 \mathrm{lbs}$. each) beautiful specimens more than fifteen years old. Just about every other year the tinfoil barbs only would have an eruption of skin lesions that was assumed to be a mycobacteriosis. When such skin eruptions presented on the barbs we routinely treated with Isoniazid (Laniazid,Nydrazid), also known as isonicotinylhydrazine (INH). Isoniazid tablets were relatively inexpensive and we would treat the entire tank by dissolving tablets in the closed system. Treatment was one dose each week until the skin eruptions cleared usually in about three weeks. This treatment was performed a number of times and never did we lose any fishes to the treatment so we considered it quite safe for any freshwater species.

Poisoning of Grass Carp 
Sometime in the early 80 's we moved the grass carp from the North American exhibit to the Asianropicals exhibit. The grass carp continued to thrive and grow amongst all the other species and overall it was a healthy community of fishes. The grass carp were in this system for some time when we noticed

skin eruptions on the tinfoil barbs. As was our routine we treated the tank late one afternoon with Isoniazid. Much to our surprise we found all of the grass carp, and only the grass carp, dead the following morning. All of the other Asian fishes were fine. Water quality was fine and we could not find anything out of the ordinary with the exception of the Isoniazid treatment. There were no outward signs of note on the dead grass carp. We did not do a necropsy on the grass carp and just assumed they were super sensitive to the Isoniazid. Again, this was surprising in the context of other carp-like tank mates that were not impacted. Unfortunately,I cannot remember the dosage rate of the specifics on the Isoniazid tablets but vaguely recall it as around 2000 tablets for the 12,000 gallon system.

\title{
Environmental Conditions
}

The 12,000 gallon system had been established for many years. The water source was dechlorinated Cleveland domestic water from Lake Erie with a pH 7.6 and temperature of 78 degrees $\mathrm{F}$. It was a recirculated system with excellent biological filtration operated by large air lift water pumps that insured very efficient aeration and dissolved oxygen. Biological filtration did not appear to be interrupted by-the Isoniazid. There was a trickle system that delivered about $1 \mathrm{gpm}$ of dechlorinated water and we performed additional routine $50 \%$ water changes every few months. There was no detectable ammonia/ammonium or nitrites. Idon't recall the upper levels of nitrates but they were very low due to the trickle system.

\section{Supposition}

At best this is a small case study but admittedly an anecdotal story as it is not supported by records. At the time we found it interesting that grass carp would be so sensitive to Isoniazid but we did not perform any further investigations nor did we get more grass carp for the collection. Might Isoniazid or one of its components have a field application for the control of grass carp? I have no idea if it would be practical or what environmental impacts it might have if applied. Nonetheless, I wanted to share this story with you should it provide a clue for your work ahead.

My contact information is below should you or your staff want to contact me. I wish you all the best in the great challenge to understand and maintain the biological diversity of our nation's rivers and lakes.

Sincerely,

\author{
Ed Bronikowski \\ Senior Curator \\ Department of Animal Care Sciences \\ National Zoological Park \\ Smithsonian Institution \\ MRC 5507,Washington,DC 20013-7012 USA \\ Ph 202-633-32481 cell 202-498-1283 \\ email bronikowski@si.edu \\ www.nationalzoo.si.edu
}




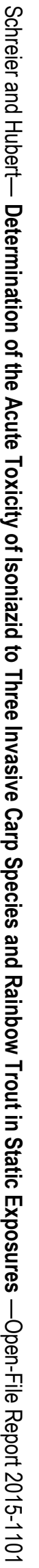

